\title{
THEORETICAL ASPECTS OF HARMONIZATION OF UKRAINIAN TAX SYSTEM IN CONTEXT OF BEHAVIORAL FINANCE
}

\author{
L. V. BARABASH, Candidate of Economic Sciences \\ Uman National University of Horticulture
}

У статті розглянуто особливості функиіонування податкової системи України з позииії впливу різнопланових аспектів. Увагу зосереджено на поведінкових чинниках, як причинно-наслідковому факторі провадження оподаткування. 3'ясовано перспективні напрями гармонізащії провадження податкової системи з позииії поведінкових фінансів.

Ключові слова: податкова система, податкова гармонізачія, поведінкові фінанси, поведінкові фактори, сочіальна справедливість

Problem statement. The tax system of Ukraine was established in the 90s of the last century, and in 2011, with the implementation of the Tax Code of Ukraine, it was reformed, which aimed to simplify taxation for taxpayers and help increase its efficiency at the national level. However, the expected effect was not achieved, due to a number of various obstacles. Now, in order to substantiate the need to find priority vectors for harmonization of the national tax system, it is worth paying attention to the index of its competitiveness in comparison with the tax systems of foreign countries, which in this ranking 137. Thus, in 2017-2018, Ukraine is ranked 81 st in terms of productivity, improving its position by a total of 654 points compared to 2012-2013, and was included in the ranking of the Top-25 countries with the highest level of taxation is ranked 23-d position [6]. So far, the situation has not changed dramatically, so the question of finding relevant and effective directions for the development of Ukrainian tax system is still relavant.

It is also appropriate to indicate the range of its typical shortcomings. These include: low degree of progressivity in tax rates, high levels of tax burden on business, the prevalence of indirect taxation over direct, lack of equity in the taxation of income and profits, ineffectiveness of resource and environmental taxation etc. At the same time, not only economic factors have a negative impact on the functioning of the tax system: socio-sociological factors and behavioral aspects of the interaction between taxpayers and the state play an important role.

Analysis of recent research and publications. In modern financial and economic system of countries, taxes are the monopoly law of the state. Therefore, the tax system, together with the arrangement of its functioning, is a non-competitive tool. However, the implementation of this mechanism in practice requires. in addition to rapid and effective responses to changes in the financial and economic environment, taking into account the needs of society as a whole and individual groups of payers in particular. 
Currently, the transformation of the native financial and economic environment is caused by a number of internal and external factors. And the biggest economic distortions are due to the global pandemic of COVID-19, which has spread throughout the world economy. At the same time, it is the crisis phenomena that provoke radical changes in tax systems, determining their long-term priorities. At one time, J. Schumpeter called such a phenomenon the «thunder of history». However, the modern «thunder of history» takes place in the context of reducing the importance of social goals of the state and shifting the emphasis from the regulatory function of taxes to fiscal, and therefore requires urgent revision of methods and approaches of taxation, diversion and re-evaluation of the entire tax system.

Describing the potential of tax systems in the post-pandemic period, R. Arezka and G. Rota-Graziosi suggest that the COVID-19 crisis is an opportunity to restore the «civil agreement» based on strengthening the role of the state in protecting the population from health risks. social protection programmes. And the general goal is to form an effective state and tax system [14]. Vegel S., E. Visser, F. Greenfield and T. Corbett believe that in a crisis post-pandemic economy, «governments may be able to improve the neutrality, proportionality, practical administration and security of the tax to make better use of it to their citizens» [15].

Dunkelberg and J. Skorburg, who conducted an experiantial research of the impact of the tax burden on US economic growth in the late twentieth century, concluded that high taxes provoke an economic recession: «The study provides reliable statistics that show that taxes cause significant harm to the economy. Since 1960, the increase in taxes (total tax revenues as a percentage of GNP) has inevitably led to a slowdown in economic growth and recession» [10, p. 160]. This confirms the opinion that the harmonization of the tax system of Ukraine should take place, first of all, on the basis of the prevalence of social goals.

We find a similar opinion in I. Sharovska, who, analyzing the tax burden of the EU in 1995-2010, came to the conclusion that «the bilateral relationship between changes in the tax burden on consumption and GDP growth, while capital and labor are characterized by one-way casual communication» [16, p. 1159].

In conducting a study of the impact of the tax burden on economic growth in Ukraine, A. Vdovychenko and G. Oros testify to the high level of fiscal and tax burden in Ukraine, noting at the same time: «...will inevitably lead to a further imbalance of public finances, as compensation for lost government revenues will occur due to accelerated economic growth» [2, p. 76]. Thus, based on the above opinions of scientists, we can say that taxes, provided they are rational and harmonious functioning, have a significant impact on economic growth.

Focusing on the prospects for optimizing taxation in the aftermath of a pandemic, EK Craig and JR Hinesmall. note «... it is reasonable to consider the most cost-effective means of solving the problems that are dragging on by the pandemic. In particular, taxes can be used to create flexible incentives for individuals and контролю to control the environment and other externalities» [9]. Summarizing these views, it should be noted that in the post-pandemic perspective, the domestic tax system needs to be harmonized from the standpoint of optimizing the impact of various influencing factors with a focus on social and behavioral demands of society. 
Research methodology. The research was based on the dialectical method of cognition. The method of analysis became core in the process of elaboration of existing and identification of perspective theoretical bases of harmonization of Ukrainian tax system in the context of behavioral finances. The assessment of modern features of the functioning of the tax sphere is carried out using the empirical method. Using the methods of analysis and synthesis, key behavioral factors influencing the efficiency of the tax system of Ukraine were identified. The induction method was used to summarize the results of the study and to formulate conclusions.

Research results. Pursuing vigously the reform in the tax sphere in modern conditions requires a review of approaches to their implementation. And such actions require a specific definition of the process and the formation of an effective concept of its harmonization with the defined conceptual apparatus. The term «harmony», which is basic in concept of «harmonization», is interpreted by V. Dahl's dictionary as «consistency, harmony in the combination of something» [5, p. 103]. In the Dictionary of the Ukrainian language it is considered as «Combination, coherence, mutual correspondence of qualities (objects, phenomena, parts of the whole)» [4].

A. Kuznetsov, examining the interpretation of the definition of «harmony» from different positions, notes the following: «In philosophy, harmony is considered as a category that depicts the logical nature, internal consistency, integrity, and conformity of content and form. ... In aesthetics is a concept that means order, integrity, diversity, coherence of parts. ... In Latin science... - «Everything that consists of opposites» is an understanding of the contradictory and the opposite. In the classical literature, harmony was described as «concordia discors» - «consent of the contradictory» [3]. That is, there is a clear idea that «harmony» is a term that has a wide range of coverage and action.

The concept of «harmonization» has appeared among the rhetoric of the native scientific community relatively recently and raises many objections. And this is quite logical, because in native dictionaries the term «harmonization» is directly related exclusively to the field of music [4, p. 32]. It should be noted that fairly recently the economic community has begun to consider harmonization in the relevant field, but mainly in terms of harmonization of legislation, standards and other legal norms of Ukraine and foreign countries, mainly the European Union.

At the same time, A. Chmut, studying the economic essence of the concept of «harmonization» and comparing it with the concepts of «optimization», «harmonization / balancing», «equilibrium», «unification» is inclined to believe that «... harmonization in the economy means aimed at mutual, balancing, optimization, unification, coordination of actions and economic processes in order to achieve balance and coordination» [7, p. 232-235].

At the same time, foreign science consider harmonization as «... the process of minimizing redundant or contradictory standards that could develop independently», concentrating on the standardization of processes [13]. The definition of «tax harmonization», which is considered as the process of adjusting the tax systems of different jurisdictions to achieve a common policy goal, is considered separately. Tax harmonization includes the elimination of tax distortions that affect the movement of goods and factors to ensure a more efficient allocation of resources in an integrated 
market. Tax harmonization can serve alternative purposes, such as equity or stabilization. This can also be attributed, along with the harmonization of public spending, to the broader concept of fiscal harmonization» [17].

In the national financial and economic system, harmonization in the field of taxation is considered from the standpoint of harmonization of tax legislation and tax mechanisms between countries that are in friendly relations. However, today, in conditions of low efficiency of the tax system of Ukraine, the internal structure of the system, balancing different types of taxes in it, as well as the interests of the state and taxpayers need harmonization.

Thus, we see that «harmonization», as a concept, is quite broad, and its relevance in the field of economics and finance in modern conditions is undeniable.

In Ukraine, the harmonization of the tax system should be carried out taking into account various factors influencing it. In particular, it is quite logical to assume the implementation of conditions for a balanced and efficient tax system by regulating the fiscal financial interests of the state and the expectations and capabilities of taxpayers in the medium and long-term planning. After all, it is the predominance of social goals over fiscal interests in the medium term that forms the preconditions for strengthening the fiscal component in the long run.

One of the main theories of behavioral finance - the expected utility - was used in the context of studying the impact of behavioral factors on the functioning of the tax system and identified two different models of taxpayers' approaches to taxation: unconventional, based on irrational utility, and social interaction in traditional within [11]. The first testified to the facts of tax evasion, provoked by the desire of taxpayers to avoid losses and non-linear weighing of the probability of risk and punishment. As for the model of social interaction, in this case the specific social, sociological and cultural environment of the payer, in which fines for violating tax norms are regarded as unacceptable significant psychological losses that provoke a decrease in prestige and violation of group norms, led to avoidance. Interestingly, in both cases, as a rule, the logic of collective action works mainly.

Therefore, when focusing on building a harmonious tax system, behavioral factors must be taken into account. The principle of social justice in its two-vector nature should be dominant: the first direction concerns the government, when funds are needed to cover the necessary expenses, including social security and economic development of the state and territories, and the second - directly to taxpayers, their incomes, living standards and tax capacity. And if public services are provided of poor quality, taxpayers consider tax payments unfair. The significant difference between tax payments for different taxpayers is equally estimated. Therefore, laying the foundations for the harmonious functioning of the tax system, it is necessary to identify those key factors that have a direct impact on it (Fig. 1).

Among those demonstrated in Fig. 1 group of factors influencing the tax system, relatively new to the native financial sector are behavioral factors. It is their foreign financial science has long been recognized as one of the most active in terms of influencing the formation and course of all financial and economic processes. At the same time, the preconditions that determine the nature of such factors are hidden as the tax system implements the principle of social justice. 


Economic development of the country and regions;
The level of average wages;
The level of tax capacity of the population;
The level of redistribution of GDP;
The presence and size of inflation.

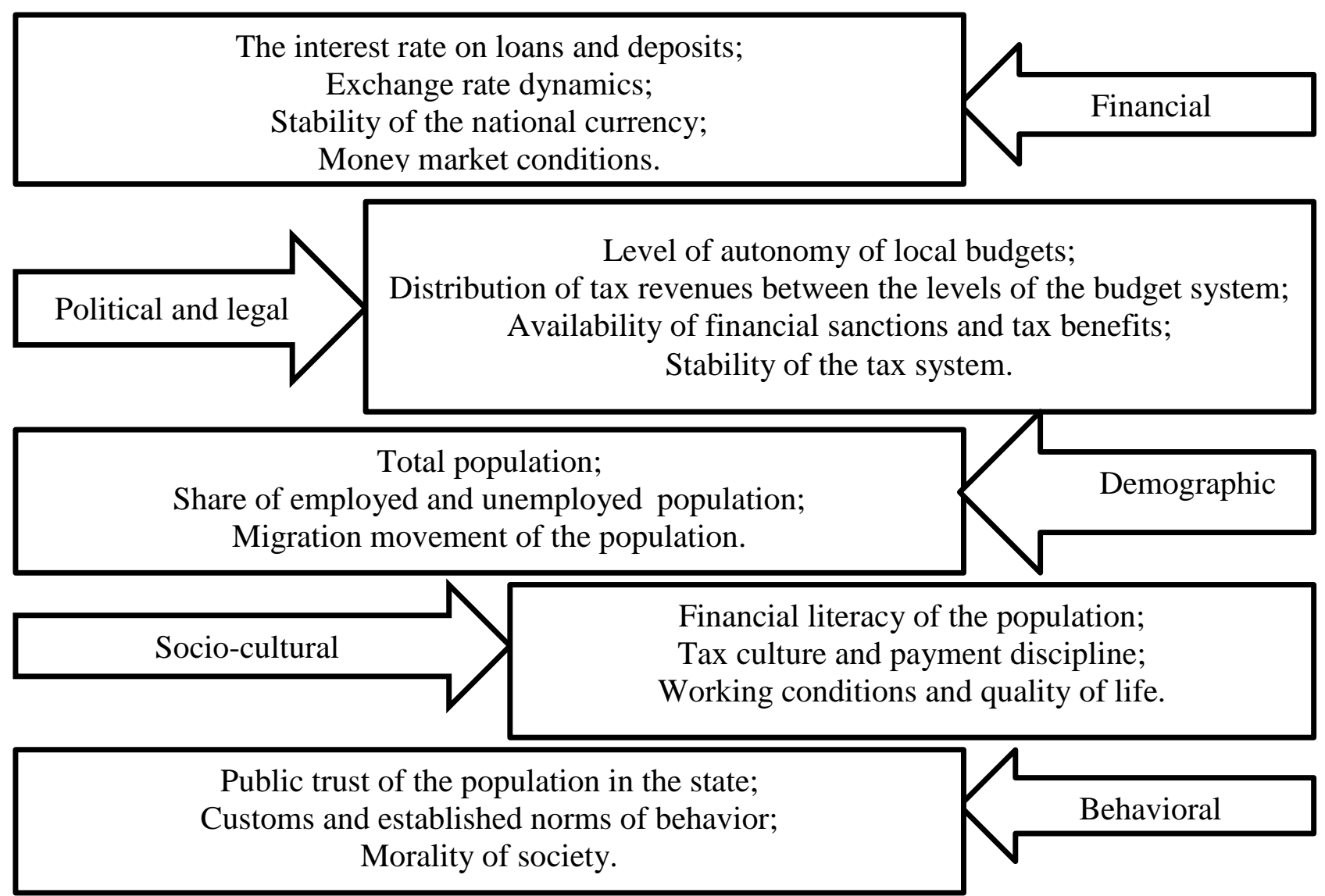

\section{Fig. 1. Groups of factors influencing the tax system * \\ * Generalized by the author for [1]}

Depending on the priority of the state, the behavior of taxpayers is determined: they choose either the side of legal taxation or evade it. "Tax fairness is considered a non-economic variable that determines tax evasion and is an important decisionmaking factor for taxpayers», claim a group of foreign researchers [12].

And tax evasion itself is becoming the standardized for a society where taxes perform a predominantly fiscal function. Support for this position is found in groups of scholars from Jordan, who note: "When the government, by increasing taxes, introduces a new tax, it can increase the burden on taxpayers, thereby encouraging them to participate in tax evasion» [8]. When paying attention to the behavioral aspects of the functioning of the tax system, it is first necessary to find out which of these two phenomena is motivating and which is consequential. However, the unequivocal statement that behavioral aspects are a provoking factor in the effectiveness of the tax system is false. After all, it is quite logical that it is the tax system that shapes the appropriate behavior of the population, enterprises and entrepreneurs in the financial and economic environment. 
Conclusions. Focusing on the behavioral factors influencing the efficiency of the tax system, we should focus on three main points: public confidence in the state; customs and established norms of behavior; morality of society. All of them are determined by signs not only of economic, social and psychological, but also historical nature, because they arose in different periods of time, under different economic conditions, which contributed to the formation of different goals and values, and thus - the behavior of individuals, social groups and society. In this case, economic behavior has both material content, which is responsible for labor and its product, and socio-economic form, which determines social relations. Both highquality and efficient market, sustainable economic development and socially oriented state contribute to the change of established preferences and traditions and increase the level of harmonization and efficiency of the tax system.

Thus, the need for state support and harmonization of the tax system in accordance with the conditions of behavioral finance is currently indisputable. And to act according to the logical chain "need $\rightarrow$ interest $\rightarrow$ motivation $\rightarrow$ action" relevant in the conditions of behavioral finance.

\section{Література}

1. Богуславська А. О., Набатова Ю. О. Фактори впливу на обсяги податкових надходжень місцевих бюджетів. Ефективна економіка. 2017. № 9. URL: http://www.economy.nayka.com.ua/?op=1\&z=5773

2. Вдовиченко А. М., Орос Г. В. Податкове навантаження і темпи економічного зростання в Україні: у пошуках раціонального співвідношення. Економіка України. 2014. № 8. С. 61-78.

3. Кузнецов А. Гармонія як баланс (рівновага) чи як цілісність (узгодженість, єдність заради одного). 04 січня 2019. URL: https://ukua.vedavrat.org/Jyotish/12149/harmony-balance-equilibrium-or-integrityconsistency-unity-opposite-for-one (дата звернення 05.05.2021)

4. Словник української мови: в 11 томах. Том 2, 1971. С. 32-33.

5. Толковый словарь живого великорусского языка: в 4 томах / В. И. Даль. М. : Русский язык, 1998 г. 2726 с.

6. Хотенко О. Актуальні напрями реформування вітчизняної податкової системи. ГО «Інститут податкових реформ». 2019. 25 березня. URL: https://ngoipr.org.ua/news/aktualni-napryamy-reformuvannya-vitchyznyanoyipodatkovoyi-systemy/ (дата звернення 10.04.2021)

7. Чмут А. В. Оцінка рівня гармонізації відносин учасників інтеграційних об'єднань. Збірник наукових пращь Харківського національного аграрного університету. 2012. № 6. С.232-237.

8. AlAdham, M., Abukhadijeh, M. A., \& Qasem, M. F. (2016). Tax evasion and tax awareness evidence from Jordan. International Business Research. № 9 (12). P. 65-75.

9. Ashley C. Craig, James R. Hines Jr. Taxes as Pandemic Controls. June $2020 . \quad$ URL: https://sites.lsa.umich.edu/ashcraig/wpcontent/uploads/sites/716/2020/07/covid_craighines.pdf

10. Dunkelberg W., Skorburg J. How Rising Tax Burdens Can Produce Recession. Cato Policy Analysis. 1991. №. 148. P. 159-164.

11. European Commission. Taxation Paper № 41 - Behavioural Economics and Taxation. Luxembourg: Publications Office of the European Union 2014. 37 pp. URL: 
https://ec.europa.eu/taxation_customs/sites/taxation/files/resources/documents/taxatio n/gen_info/economic_analysis/tax_papers/taxation_paper_41.pdf

12. Farrar, J., Kaplan, S. E., \& Thorne, L. (2017). The effect of interactional fairness and detection on Taxpayers compliance intentions. Journal of Business Ethics. № 147 (707). P. 1-14.

13. Harmonization (standards).

URL: https://en.wikipedia.org/wiki/Harmonization_(standards)

14. Rabah Arezki and Grégoire Rota-Graziosi COVID-19's 'thundering' effect on taxes. Brookings. February 18, 2021. URL: https://www.brookings.edu/blog/future-development/2021/02/18/covid-19sthundering-effect-on-taxes/

15. Stef van Weeghel, Tom Corbett, Edwin Visser, Phil Greenfield COVID19: The impact on VAT/GST systems. Tax Policy Bulletin from Global Tax Policy. June 10, 2020. URL: https://www.pwc.com/gx/en/tax/newsletters/tax-policybulletin/assets/pwc-covid19-the-impact-on-vatgst-systems.pdf.

16. Szarowska I. Shift In Tax Burden And Its Impact On Economic Growth In The European Union. Acta Universitatis Agriculturae Et Silviculturae Mendelianae Brunensis. 2013. № 4. P. 1153-1160

17. Tax harmonization. https://en.wikipedia.org/wiki/Tax_harmonization (дата звернення 25.05.2021)

\section{References}

1. Boguslavskaya, A. O., Nabatova, Y. O. (2017). Factors influencing the amount of tax revenues of local budgets. Efficient economy, no. 9. URL: http://www.economy.nayka.com.ua/?op=1\&z=5773 (access date 30.05.2021)

2. Vdovichenko, A. M., Oros, G. V. (2014). Tax burden and economic growth rates in Ukraine: in search of a rational ratio. Ukraine economy, no. 8, pp. 6178.

3. Kuznetsov, A. Harmony as a balance (balance) or as a whole (coherence, unity for one). January 4, 2019. URL: https://ukua.vedavrat.org/Jyotish/12149/harmony-balance-equilibrium-or-integrityconsistency-unity-opposite-for-one (accessed 05.05.2021)

4. Dictionary of the Ukrainian language: in 11 volumes. Volume 2, 1971. S. 32-33.

5. Explanatory dictionary of the living Great Russian language: in 4 volumes / VI Dal. M .: Russian language, 1998. 2726 p.

6. Khotenko, O. Current directions of reforming the domestic tax system. NGO «Institute of Tax Reforms». 2019. 25 March. URL: https://ngoipr.org.ua/news/aktualni-napryamy-reformuvannya-vitchyznyanoyipodatkovoyi-systemy/ (access date 10.04.2021)

7. Chmut, A. V. (2012). Assessment of the level of harmonization of relations of members of integration associations. Collection of scientific works of Kharkiv National Agrarian University, no. 6, pp. 232-237.

8. AlAdham, M., Abukhadijeh, M. A., Qasem, M. F. (2016). Tax evasion and tax awareness evidence from Jordan. International Business Research, no. 9 (12), pp. 65-75.

9. Ashley, C., Craig, James, R., Hines, Jr. Taxes as Pandemic Controls. June 2020. URL: $\quad$ https://sites.lsa.umich.edu/ashcraig/wpcontent/uploads/sites/716/2020/07/covid_craighines.pdf

10. Dunkelberg, W., Skorburg, J. (1991). How Rising Tax Burdens Can Produce Recession. Cato Policy Analysis, no. 148, pp. 159-164. 
11. European Commission. Taxation Paper № 41 - Behavioural Economics and Taxation. Luxembourg: Publications Office of the European Union 2014. 37 pp. URL:

https://ec.europa.eu/taxation_customs/sites/taxation/files/resources/documents/taxatio n/gen_info/economic_analysis/tax_papers/taxation_paper_41.pdf

12. Farrar, J., Kaplan, S. E., Thorne, L. (2017). The effect of interactional fairness and detection on Taxpayers compliance intentions. Journal of Business Ethics, no. 147 (707), pp. 1-14.

13. Harmonization (standards). URL:

https://en.wikipedia.org/wiki/Harmonization_(standards)

14. Rabah Arezki and Grégoire Rota-Graziosi COVID-19's «thundering» effect on taxes. Brookings. February 18, 2021. URL: https://www.brookings.edu/blog/future-development/2021/02/18/covid-19sthundering-effect-on-taxes/ (дата звернення 10.04.2021)

15. Stef van Weeghel, Tom Corbett, Edwin Visser, Phil Greenfield COVID19: The impact on VAT/GST systems. Tax Policy Bulletin from Global Tax Policy. June 10,2020 . URL: https://www.pwc.com/gx/en/tax/newsletters/tax-policybulletin/assets/pwc-covid19-the-impact-on-vatgst-systems.pdf.

16. Szarowska, I. (2013). Shift In Tax Burden And Its Impact On Economic Growth In The European Union. Acta Universitatis Agriculturae Et Silviculturae Mendelianae Brunensis, no. 4, pp. 1153-1160

17. Tax harmonization.

URL:

https://en.wikipedia.org/wiki/Tax_harmonization

Барабаш Л. В.

\section{Аннотация}

Теоретические аспекты гармонизации налогового системы Украины в условиях поведенческих финансов

Налоговая система Украины в том виде, как она сейчас функиионирует, по результативным показателями не соответствует условиям современных налоговых систем ведущих стран мира. Доказательством указанного является 84 место в рейтинге конкурентоспособности и 23 место в рейтинге Топ-25 стран с самым высоким уровнем налогообложения. Поэтому нужна гармонизация налоговой системы, чтобы упростить условия налогообложения и уменьшить налоговое бремя или усреднить его с целью снижения цен на товары или средства производства. Стоит отметить, что сейчас гармонизачию рассматривают преимущественно как согласование норм функиионирования налоговых систем различных стран в рамках сотрудничества и достижения взаимных положительных эффектов. Однако каждое государство имеет свои экономические особенности и национальные традииии, которые находят отражение и в функиионировании налогов. Поэтому гармонизачия, как явление экономического характера, вполне применимо внутри конкретной налоговой системы.

Среди множества факторов влияния на функиионирование налоговой системы, для отечественной экономической среды относительно новой является группа поведенческих аспектов. В их основе - привычки, традиции и культура населения, общественное сознание и уровень психологической $u$ сочиальной напряженности в обществе. Хотя справедливо будет отметить, что возникают и усугубляются поведенческие факторы под влиянием других групп параметров.

И одним из таких является уровень фискализации экономики и ее базиса налоговой системы. Высокий уровень фискализации налоговой системы 
сформировал у плательщиков негативное отношение к налогообложению, что усилило теневые тенденции в экономике государства. Несоответствие сумм уплачиваемых налогов качеству и объемам получаемых от государства услуг и благ, а также низкий уровень сочиальных гарантий вызвали общий когнитивный дисонанс. Трансформировавшись в предубеждение, он приобрел общеначиональный сочиальный характер, сформировав модель экономического поведения, которая фактически отрищает определяюшую роль государства в жизни современного индивида. Поэтому следует подчеркнуть, что гармоничное функиионирование налоговой системы должно основываться на комплексности подходов, с учетом факторов разнопланового характера. И с данной позичии поведенческие финансы становятся фактором ключевого и непосредственного влияния.

Ключевые слова: налоговая система, налоговая гармонизачия, поведенческие финансы, поведенческие факторы, сочиальная справедливость

Barabash L. V.

\section{Annotation}

\section{Theoretical aspects of harmonization of Ukrainian tax system in the context of behavioral finance}

The tax system of Ukraine in the way in which it now operates, in terms of performance does not meet the conditions of modern tax systems of the world's leading countries. Proof of this is 84th place in the ranking of competitiveness and $23 r d$ place in the ranking of the Top 25 countries with the highest level of taxation. Therefore, harmonization of the tax system is needed to simplify tax treatment and reduce the tax burden or average it in order to reduce the prices of goods production means. It is noteworthy that harmonization is now considered primarily as the harmonization of the standards of the tax systems of different countries in the framework of cooperation and the achievement of mutual positive effects. However, each state has its own economic traits and national traditions, which are reflected in the functioning of taxes. Therefore, harmonization, as a phenomenon of an economic nature, is quite applicable within a particular tax system.

Among plenty of factors influencing the operating of the tax system, a group of behavioral aspects is relatively new for the native economic environment. They are based on the habits, traditions and culture of the population, public consciousness and the level of psychological and social tension in society. Although it is notable that behavioral factors arise and worsen under the influence of other groups of parameters.

And one of these is the level of fiscalization of the economy and its basis - the tax system. The high level of fiscalization of the tax system has formed a negative attitude of taxpayers to taxation, which has intensified the shadow trends in the state economy. The inconsistency between the amounts of taxes paid and the quality and amount of services and benefits received from the state, as well as the low level of social guarantees, caused a general cognitive dissonance. Transformed into a prejudice, he acquired a national social character, forming a model of economic behavior that in fact denies the defining role of the state in the life of the modern individual. Therefore, it should be emphasized that the harmonious functioning of the tax system should be based on a comprehensive approach, taking into account various factors. And from this point of view, behavioral finance becomes a factor of core and direct influence.

Key words: tax system, tax harmonization, behavioral finance, behavioral factors, social justice 